\title{
Detection of polymorphic patterns of genomic DNA amplified by RAPD-PCR in sweet potato weevils, Cylas formicarius (Fabricius) (Coleoptera: Brentidae)
}

\author{
Kiyohisa Kawamura, Tuyosi Sugimoto, ${ }^{*}$ Yoshinori Matsuda ${ }^{1}$ and Hideyoshi Toyoda ${ }^{1}$ \\ Entomological Laboratory, Faculty of Agriculture, Kinki University, Nara 631-8505, Japan \\ ${ }^{1}$ Laboratory of Plant Pathology and Biotechnology, Faculty of Agriculture, Kinki University, Nara 631-8505, Japan \\ (Received 1 July 2002; Accepted 21 August 2002)
}

\begin{abstract}
The polymorphic patterns of genomic DNA amplified by RAPD-PCR were detected in laboratory-cultured populations of sweet potato weevils, Cylas formicarius collected from the Southwest islands (Nansei-Shoto) of Japan. When three sets of primers, T13/T13, T05/T05 and T01/T07 were used for PCR, the polymorphic patterns of the amplified DNA were classified into nine types. Of these types, $\mathrm{A}_{1} \mathrm{~B}_{1} \mathrm{C}_{3}$ was common in all populations tested. The present study determined the useful primer sets that will enable the successful classification of sweet potato weevils based upon the polymorphic patterns of genomic DNA amplified by RAPD-PCR.
\end{abstract}

Key words: Cylas formicarius, polymorphism, RAPD-PCR, classification

\section{INTRODUCTION}

Sweet potato weevil, Cylas formicarius (Fabricius), a serious insect pest of sweet potato, is distributed widely over 50 countries in the tropic and subtropic areas of the world (IIE, 1993). This weevil was first recorded on Okinawa Island Japan in 1903 (Nawa, 1903), and afterward spread to Amami Islands by the 1940s (Setokuchi et al., 1996). Owing to damage to sweet potato by this weevil, the export of sweet potato from the infested area has been strictly prohibited under the plant quarantine regulation since 1950 . Nevertheless, the weevil has often accidentally been transferred with damaged tubers to undistributed areas in Japan (Setokuchi et al., 1996). Hence, it is of practical importance to precisely trace the expanding geographical distribution of this pest.

Polymorphic DNAs are frequently detected in genomic DNAs randomly amplified by polymerase chain reaction using random primers (RAPD-PCR) (Williams et al., 1990). This method has provided a useful tool to rapidly distinguish insects by the polymorphic patterns of their DNA. One of the most prominent features of RAPD-PCR is that DNA amplification can be achieved by using small amounts of DNA in relevant combinations with random primers, irrespective of target DNA se- quences. Actually, this method has been used for analysis of genetic variation of insects population and for identification of cryptic insect species and biotypes (Black IV et al., 1992; Gawel and Bartlett, 1993; Black IV and DuTeau, 1997). In the present study, RAPD-PCR was conducted to identify individual sweet potato weevils collected in the Southwest islands in Japan. The present study determines the effective PCR-primers that enable us to investigate polymorphic patterns of genomic DNA of sweet potato weevils.

\section{MATERIALS AND METHODS}

Insects. Sweet potato weevils, Cylas formicarius (Fabricius) (Coleoptera: Brentidae), were collected in Amami-Oshima Island, Kagoshima Prefecture and Okinawa-Hontou Island, Okinawa Prefecture in 1996, and in Nakanoshima Island of Tokara Islands, Kagoshima Prefecture, Miyakojima Island and Ishigakijima Island, Okinawa Prefecture in 1997. These weevils were reared in successive generations on sweet potato tubers in a bio-safety incubator controlled at $27^{\circ} \mathrm{C}, 70 \% \mathrm{RH}$ and $14 \mathrm{~L}-10 \mathrm{D}$ in Kinki University, Nara Prefecture, with special permission of the Japanese government. Adults were frozen at $-20^{\circ} \mathrm{C}$ for DNA extraction and subsequent amplification by polymerase chain reaction.

* To whom correspondence should be addressed at: E-mail: sugimoto@nara.kindai.ac.jp 
DNA extraction. DNA was extracted from individual weevils by a slightly modified method of Maekawa et al. (1998). The insects were individually homogenized in $200 \mu \mathrm{l}$ of $100 \mathrm{~mm}$ EDTA (pH 8.5 ) with a mortar and pestle, and the homogenate was mixed with $200 \mu \mathrm{l}$ of $50 \mathrm{~mm}$ Tris- $\mathrm{HCl}(\mathrm{pH} 7.8)$ containing $100 \mathrm{~mm}$ EDTA, $50 \mathrm{~mm} \mathrm{NaCl}$ and $0.2 \%$ SDS. The mixture was treated with RNase A (Sigma, St. Louis, MO, USA) at $10 \mathrm{mg} / \mathrm{ml}$ and Proteinase K (Promega Biotech, Madison, WI, USA) at $100 \mu \mathrm{g} / \mathrm{ml}$ at $37^{\circ} \mathrm{C}$ for $30 \mathrm{~min}$. The sample was deproteinized by addition of organic solvents (phenol: chloroform: isoamyl alcohol, 25:24:1 v/v) and centrifuged at $12,000 \times g$ for $15 \mathrm{~min}$. Finally, DNA was precipitated by addition of 2-propanol, rinsed with $400 \mu \mathrm{l}$ of $70 \%$ ethanol, dried under vacuum and dissolved in $10 \mathrm{~mm}$ Tris- $\mathrm{HCl}(\mathrm{pH} 7.5)$ containing $1 \mathrm{~mm}$ EDTA.

PCR amplification. Extracted DNA (10 ng) was dissolved in $25 \mu \mathrm{l}$ of $150 \mathrm{~mm}$ Tris- $\mathrm{HCl}(\mathrm{pH} \mathrm{8.0)}$ containing $500 \mathrm{mM} \mathrm{KCl}, 2.5 \mathrm{mM} \mathrm{MgCl}_{2}, 2 \mathrm{mM}$ dNTPs, $5 \mathrm{pm}$ of primers and $0.5 \mathrm{U}$ of DNA polymerase. The twenty primers were purchased from Operon Technologies (Alameda, CA, USA) and used for PCR in thirty combinations: T01/T01, T02/T02, T03/T03, T04/T04, T05/T05, T06/T06, T07/T07, T08/T08, T09/T09, T10/T10, T11/T11, T12/T12, T13/T13, T14/T14, T15/T15, T16/T16, T17/T17, T18/T18, T19/T19, T20/T20, T01/T02, T01/T03, T01/T04, T01/T05, T01/T06, T01/T07, T01/T08, T01/T09, T01/T10 and T01/T11. DNA polymerase and deoxynucleotide mixtures (AmpliTaq Gold with GeneAmp) were from Applied Biosystems (Foster City, CA, USA). PCR was conducted according to the methods of Williams et al. (1990); initial heat step $\left(93^{\circ} \mathrm{C}\right.$ for $\left.10 \mathrm{~min}\right), 45 \mathrm{cy}-$ cles of denature $\left(94^{\circ} \mathrm{C}\right.$ for $\left.1 \mathrm{~min}\right)$, annealing (between 33 and $36^{\circ} \mathrm{C}$ for $\left.1 \mathrm{~min}\right)$, extension $\left(72^{\circ} \mathrm{C}\right.$ for $2 \mathrm{~min})$ and final step $\left(72^{\circ} \mathrm{C}\right.$ for $\left.5 \mathrm{~min}\right)$. Amplification was performed using a GeneAmp 2400 Thermal Cycler (Applied Biosystems). Procedures for PCR were carried according to the instructions of Kwok and Higuchi (1989).

\section{RESULTS AND DISCUSSION}

Molecular identification of insects has been frequently conducted on the basis of existence of demonstrative polymorphic DNA fragments amplified by PCR (Caterino et al., 2000). For example,
Williams et al. (1994) reported geographical distribution of Argentine stem weevils, Listronotus bonariensis (Kuschel), by RAPD-PCR of genomic DNAs. Haymer and McInnis (1994) also pointed out a distinctive variation in PCR-amplified DNA patterns between laboratory-cultured and wild populations of Mediterranean fruit flies, Ceratitis capitata (Weidemann). We have attempted to clarify PCR-based DNA patterns in sweet potato weevils collected from various areas of the Southwest islands of Japan.

Figure 1 shows electrophoretic patterns of DNA fragments amplified by the different primer sets. Of the primer sets used, T13/T13 (A in Fig. 1), T05/T05 (B) and T01/T07 (C) revealed the specific polymorphic DNA patterns that enabled us to distinguish individual sweet potato weevils. The polymorphic patterns were reproducibly observed at defined annealing temperatures; $36^{\circ} \mathrm{C}$ for $\mathrm{T} 13 / \mathrm{T} 13$ and $\mathrm{T} 01 / \mathrm{T} 07$, and $33^{\circ} \mathrm{C}$ for $\mathrm{T} 05 / \mathrm{T} 05$. Based on these results, we propose a new system for classification of sweet potato weevils by the polymorphic patterns of PCR-amplified fragments. We carried out an identification of laboratory-cultured sweet potato weevils with this system. Namely, the tested weevils were first classified into two types $A_{1}$ and $A_{2}$ by T13/T13, secondly into two types $B_{1}$ and $B_{2}$ by T05/T05 and finally into four types $\mathrm{C}_{1}$ to $\mathrm{C}_{4}$ by T01/T07. Eventually, each insect was given as triple notation determined by three steps of PCR analysis. Using this procedure, sweet potato weevils in five geographic populations were examined for their polymorphic patterns of genomic DNA and nine distinctive DNA patterns were detected (Table 1). In each population of the Southwest islands, several types were recognized in the tested weevils, of which " $A_{1} B_{1} C_{3}$ " was commonly found in all populations. Although the majority of the tested weevils was assigned to type $A_{1}$ at the first PCR step, one weevil in Amami Island was type $\mathrm{A}_{2}$. Thus, we successfully determined the primers that can be used for identification of individual sweet potato weevils by RAPD-PCR analysis.

In addition, we preliminarily examined applicability of the present identification system to individual sweet potato weevils originating in other countries. The template DNA was extracted from ethanol-fixed individual weevils that were obtained from Vietnam (provided by Mr. K. Ōmura, Yokohama Plant Quarantine Station). As shown in Fig. 

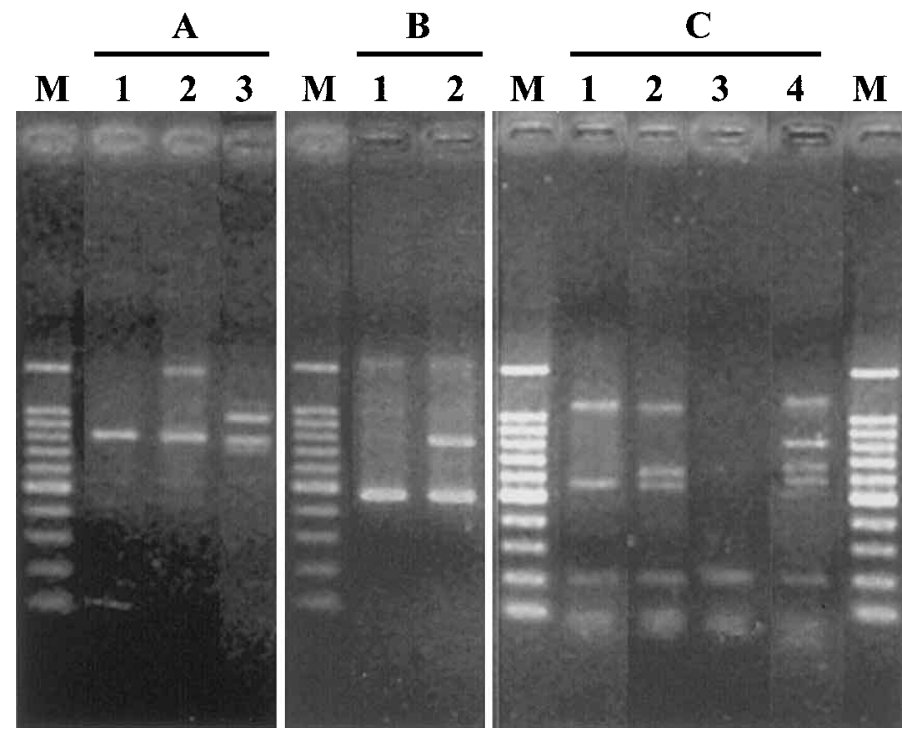

Fig. 1. PCR-amplified DNA fragments of genomic DNA obtained from individual sweet potato weevils. Three primer sets A (T13/T13, 5'-AGGACTGCCA-3'), B (T05/T05, 5'-GGGTTTGGCA-3') and C (T01/T07, 5'-GGGCCACTCA-3', 5' -GGCAGGCTGT-3') were used for PCR. Electrophoresis was conducted using 1.5\% agarose gels. Lanes 1 to 3 in A, 1 and 2 in B, and 1 to 4 in $\mathrm{C}$ represent specific polymorphic DNA patterns in tested weevils using the primer sets. Lane 3 in A shows distinctive DNA pattern detected in the weevil collected in Vietnam. Lane M represents a 100-bp DNA ladder size-marker.

Table 1. Geographic distribution of sweet potato weevils classified on the basis of polymorphic DNA patterns by RAPD-PCR

\begin{tabular}{|c|c|c|c|c|c|c|c|c|c|c|}
\hline \multirow{2}{*}{ Populations } & \multirow{2}{*}{$\begin{array}{l}\text { Total number of } \\
\text { insects tested }\end{array}$} & \multicolumn{9}{|c|}{ Number of insects in each DNA pattern } \\
\hline & & $\mathrm{A}_{1} \mathrm{~B}_{1} \mathrm{C}_{1}$ & $\mathrm{~A}_{1} \mathrm{~B}_{1} \mathrm{C}_{2}$ & $\mathrm{~A}_{1} \mathrm{~B}_{1} \mathrm{C}_{3}$ & $\mathrm{~A}_{1} \mathrm{~B}_{1} \mathrm{C}_{4}$ & $\mathrm{~A}_{1} \mathrm{~B}_{2} \mathrm{C}_{1}$ & $\mathrm{~A}_{1} \mathrm{~B}_{2} \mathrm{C}_{2}$ & $\mathrm{~A}_{1} \mathrm{~B}_{2} \mathrm{C}_{3}$ & $\mathrm{~A}_{1} \mathrm{~B}_{2} \mathrm{C}_{4}$ & $\mathrm{~A}_{2} \mathrm{~B}_{1} \mathrm{C}_{3}{ }^{\mathrm{a}}$ \\
\hline Tokara & 12 & 9 & - & 1 & - & 2 & - & - & - & - \\
\hline Amami & 13 & 7 & - & 1 & - & 3 & - & 1 & - & 1 \\
\hline Okinawa & 12 & 3 & 3 & 1 & - & 1 & 3 & 1 & - & - \\
\hline Miyakojima & 16 & - & - & 1 & 1 & 1 & 3 & - & 10 & - \\
\hline Ishigakijima & 16 & - & 7 & 4 & 2 & - & 3 & - & - & - \\
\hline
\end{tabular}

\footnotetext{
${ }^{\mathrm{a}}$ Triplet notation-identification of insects.
}

1A (lane 3), the primer set A showed a distinctive pattern $\left(A_{3}\right)$ in the Vietnam weevils, while the second step PCR was type $\mathrm{B}_{1}$ (The third step was not conducted, because of insufficient extracted DNA). These results suggest that the present system can also be applied to identification of weevils from other countries.

\section{AKNOWLEDGEMENTS}

We would like to thank Mr. K. Kinjo (Okinawa Prefectural Fruit Fly Eradication Project Office), Dr. O. Setokuchi and Mr. S. Izumi (Kagoshima Prefectural Agricultural Experiment Station) for supplying domestic sweet potato weevils and also $\mathrm{Mr}$. K. Ōmura (Yokohama Plant Quarantine Station) for Vietnam sweet potato weevils. Also, we appreciate Drs. Y. Sakuratani,
I. Kandori and T. Nonomura for their kind help. This study was partly supported by the Plant Protection of the Ministry of Agriculture, Forestry and Fisheries, Japan, Grant-in-Aid for Special Scientific Research on Agriculture, Forestry and Fisheries.

\section{REFERENCES}

Black IV, W. C. and N. M. DuTeau (1997) RAPD-PCR and SSCP analysis for insect population genetic studies. In Molecular Biology of Insect Disease Vectors: A Methods Manual (J. M. Crampton, C. B. Beard and C. Louis eds.). Chapman \& Hall, New York, pp. 361-373.

Black IV, W. C., N. M. DuTeau, G. J. Puterka, J. R. Nechols and J. M. Pettorini (1992) Use of the random amplified polymorphic DNA polymerase chain reaction (RAPDPCR) to detect DNA polymorphisms in aphids (Homoptera: Aphididae). Bull. Entomol. Res. 87: 151-159. 
Caterino, M. S., S. Cho and F. A. H. Sperling (2000) The current stage of insect molecular systematics: A thriving tower of babel. Annu. Rev. Entomol. 45: 1-54.

Gawel, N. J. and A. C. Bartlett (1993) Characterization of differences between whiteflies using RAPD-PCR. Insect Mol. Biol. 2: 33-38.

Haymer, D. S. and D. O. McInnis (1994) Resolution of populations of the Mediterranean fruit fly at the DNA level using random primers for the polymerase chain reaction. Genome 37: 244-248.

IIE (1993) Distribution Maps of Pests: Cylas formicarius (F.). Series A (Agricultural), Map Number 278, International Institute of Entomology, London.

Kwok, S. and R. Higuchi (1989) Avoiding false positives with PCR. Nature 339: 237-238.

Maekawa, K., T. Miura, O. Kitade and T. Matsumoto (1998) Genetic variation and molecular phylogeny based on the mitochondrial genes of the Damp wood termite Hodoter- mopsis japonica (Isoptera: Termopsidae). Entomol. Sci. 1: $561-571$

Nawa, U. (1903) On the sweet potato weevil. Kontyu Sekai 7: 327-330 (in Japanese).

Setokuchi, O., K. Kawasoe and T. Sugimoto (1996) Invasion of the sweet potato weevil, Cylas formicarius (Fabricius) into Southern Islands in Japan and strategies for its eradication. In Proc. Int. Workshop on the Pest Management Strategies in Asian Monsoon Agroecosystems (N. Hokyo and G. Norton eds.). KNAES, Kumamoto, pp. 197-207.

Williams, C. L., S. L. Goldson, D. B. Baird and D. W. Bullock (1994) Geographical origin of an introduced insect pest, Listronotus bonariensis (Kuschel), determined by RAPD analysis. Heredity 72: 412-419.

Williams, J. G. K., A. R. Kubelik, K. J. Livak, J. A. Rafalski and S. V. Tingey (1990) DNA polymorphisms amplified by arbitrary primers are useful as genetic markers. $\mathrm{Nu}$ cleic Acids Res. 18: 6531-6535. 